\title{
Sickening Pain
}

National Cancer Institute

\section{Source}

National Cancer Institute. Sickening Pain. NCI Thesaurus. Code C101166.

A sensation of discomfort or distress that makes the individual queasy or nauseated. 